\title{
Synthesis of Adenine-based Fluorescent and Naked-eye Chemosensors: Specific DNA Probes for the Detection of Bacterial Pathogens
}

\author{
Burak Şener, ${ }^{1}$ Ömür Baysal, ${ }^{1, *}$ Said Nadeem ${ }^{2}$ and Ragıp Soner Silme ${ }^{3}$ \\ ${ }^{1}$ Department of Molecular Biology and Genetics, Faculty of Science, Muğla Sitkı Koçman University, \\ Menteşe-Muğla, 48121, Turkey \\ ${ }^{2}$ Adnan Menderes Technology Development Incorporation (ADU Technopark), Aydin Adnan Menderes University, \\ 80b, Efeler-Aydin, Turkey \\ ${ }^{3}$ Center for Research and Practice in Biotechnology and Genetic Engineering, Istanbul University, \\ Istanbul, Turkey \\ * Corresponding author: E-mail: omurbaysal@mu.edu.tr \\ Tel. +90 252 2113240; Fax. +90252 2111472
}

Received: 02-12-2021

\begin{abstract}
A rapid and confident tool to identify and diagnose bacterial pathogens with more accuracy using DNA as fingerprints is necessary. Herein, we report a smart chemosensor having a terminal adenine sticking to the thymine of single-stranded DNA (ssDNA) through supramolecular interactions and, which leaves ssDNA when the same ssDNA matches with the targeting desired DNA. We have synthesized a naked-eye coloured chemosensor with carbazole. As a model genetic material, DNA of Clavibacter michiganensis subsp. michiganensis was hybridized to ssDNA and immobilized over nitrocellulose membrane. The prepared adenine-chemosensor, by passing through the nitrocellulose-ssDNA membrane caused the formation of ssDNA nitrocellulose-ssDNA-adenine-chemosensor. FTIR results of the immobilized ssDNAs showed that the matching of same ssDNA releases the adenine-chemosensor from the surface of nitrocellulose-ssDNA that results in formation of the double stranded DNA. The selectivity of chemosensor was also confirmed with different bacterial DNA (Bacillus subtilis) as control. These data highlights accurate and reliable results of a new diagnostic kit prototype promising for further studies, which is able to diagnose DNA quickly and precisely.
\end{abstract}

Keywords: Bacterial pathogens; detection; DNA probe; kit designing; naked-eye chemosensor; nanotechnology

\section{Introduction}

Biosensors have recently become efficient analytical tools attracting the attention of researchers due to their easy, convenient and specific diagnosis potential compared to traditional methods. DNA-based method "DNA sensors or gene sensors" are specifically used for diagnosis and the detection of the targeted region. ${ }^{1-3}$ These biosensors usually relies on detecting the hybridization of the target ssDNA strand, which are complementary strands. ${ }^{1,2,4}$ The advances in molecular biology have become the reason for increasing the interest in the design of DNA hybridization-based biosensors. ${ }^{5-9}$ DNA-based biosensors can be used in many areas such as clinical, environmental and food safety issues. The principle of nucleic acid tests is based on targeted DNA-primer or probe hybridization. Nucleotide sequences called primers or probes are compatible with bacterial DNA and hybrid molecules formed after adaptation. The diagnosis is made with the direct or indirect detection of the hybrid formation. In direct detection, the hybrid detected with the presence of a reporter molecule provides signal amplification, while the product resulting from enzymatic amplification of the hybrid is detected indirectly. ${ }^{10}$

Our study aims the synthesizing analytes binding to the ssDNA which acts as a biosensor, when the same strand meets the complementary DNA strand. This hybridized complex is used to identify the target DNA with the signal to be received depending on the separation of 
the sensor. The originality of our study is using the chain of the whole target DNA as a probe. Diagnosis has been made by measuring the hybridization involving complementary and/or high similarity to the target DNA.

Many different methods can be used for the measurement of hybridization. ${ }^{1}$ In recent years, new synthesised fluorescent materials such as quantum dots (QDs), up conversion nanoparticles and nano-clusters (NCs) have been extensively investigated. ${ }^{11-13}$ As reported in a previous study, modified biosensors based on electrochemical impedance spectroscopy, gold nanoparticles (AuNPs) have also been used in diagnosis of a toxin producer bacteria $\mathrm{Ba}$ cillus cereus. ${ }^{14}$ Another diagnosis method relies on measuring the Fourier-transform infrared spectroscopy (FTIR) spectrum. As known, there are many studies on DNA-dependent diagnosis using FTIR and Raman spectra. ${ }^{15-17}$ In FTIR analysis, samples are exposed to infrared radiation. Infrared radiation activates the atomic vibrations in molecules and, specific absorption or transmission peaks are formed. This makes the FTIR technique very useful for molecular diagnostics cause of rapidly characterization with sensitivity and accuracy. ${ }^{18,19}$ Infrared spectra (IR) are divided into three spectra according to their wavelengths. These are far-IR $\left(<400 \mathrm{~cm}^{-1}\right)$, mid-IR $\left(400-4000 \mathrm{~cm}^{-1}\right)$ and nearIR (4000-13000 $\left.\mathrm{cm}^{-1}\right)$ spectra. The most commonly used spectrum is the mid-IR spectrum consisting of four different parts; single bond region $\left(2500-4000 \mathrm{~cm}^{-1}\right)$, triple bond region $\left(2000-2500 \mathrm{~cm}^{-1}\right)$, double bond region (1500-2000 $\left.\mathrm{cm}^{-1}\right)$, fingerprint region $\left(600-1500 \mathrm{~cm}^{-1}\right) .^{20,21}$

The aim of our study is to synthesize molecules that can act as sensors binding to single-stranded DNA, and to make fast and sensitive DNA diagnosis with the help of FTIR spectra to be obtained based on the hybridization of these molecules with target DNA. As a result of our preliminary studies, we distinguished the same/different species on the basis of DNA matching.

\section{Experimental}

\section{1. Synthesis of Fluorescent Chemosensor}

The fluorescence-based chemosensor was synthesized in three steps; alkylation of dihydroxybenzophenone, McMurry reaction and alkylation of adenine.

\section{1. 1. Alkylation of 4,4-dihydroxybenzophenone}

(1)

4,4-dihydroxybenzophenone (DBP) was chosen as the starting material for the synthesis of the Burak Synthesis Product (BSP-3) chemosensor. DBP was alkylated using Williamson ether synthesis (WES). For this purpose, $20 \mathrm{~mL}$ acetone, $0.43 \mathrm{~g}$ dihydroxybenzophenone, $700 \mu \mathrm{L}$ dibromopropane and $1.38 \mathrm{~g}$ potassium carbonate were mixed as shown in Scheme 1. The reaction was followed by Thin-layer chromatography (TLC). After 2 hours stirring at $60^{\circ} \mathrm{C}$, reaction mixture was extracted with chloroform, dried with sodium sulphate and evaporated using rotary evaporator. The crude extract was subjected to column chromatography using hexane and ethyl acetate $(1: 1, \mathrm{v} / \mathrm{v})$. Pure alkylated DBP paste was dried and subjected to hydrogen-1 NMR (HNMR) (Bruker Ultrashield Plus Biospin- Avance III $400 \mathrm{MHz}$ NaNoBay FT-NMR).

\section{1. 2. McMurry Reaction (2)}

Alkylated DBP (1) was forwarded to McMurry reaction to put fluorescence properties into the molecule. For this purpose, $0.566 \mathrm{~g}$ of zinc powder, $10 \mathrm{~mL}$ of Tetrahydrofuran (THF), and $0.476 \mathrm{~mL}$ of $\mathrm{TiCl}_{4}$ were added into a dried flask and mixed on a magnetic stirrer as shown in Scheme 2. The mixture was refluxed at $90^{\circ} \mathrm{C}$ for two hours. $0.2 \mathrm{~g}$ of diphenylketone was transferred into the flask and refluxed further for 4 hours. The mixture obtained was poured into $10 \% 30 \mathrm{~mL} \mathrm{~K}_{2} \mathrm{CO}_{3}$ and vortexed for five minutes. It was left to dry after filtering and washing processes. The mixture obtained was separated by column chromatography and visualized under UV on the TLC layer. The photophysical properties of the product were determined by Perkin Elmer LS 55 fluorescence spectroscopy. The molecular structure of the product was checked by HNMR analysis.

\section{1. 3. Alkylation of adenine using the McMurry product (3)}

Adenine was attached to the McMurry product to obtain the final DNA-based chemosensor. After the necessary calculations, $0.076 \mathrm{~g}$ of adenine base was added to the dissolved (0.5g) McMurry product with acetone and mixed in a magnetic stirrer for 24 hours at $60^{\circ} \mathrm{C}$ as shown<smiles>O=C(c1ccc(O)cc1)c1ccc(OCCCBr)cc1</smiles>

Scheme 1. Alkylation of 4,4-dihydroxybenzophenone using Williamson ether synthesis. 
<smiles>O=C(c1ccccc1)c1ccccc1C(=O)c1ccc(OCCC[18F])cc1</smiles>

Scheme 2. McMurry reaction of alkylated benzophenone.<smiles>Nc1ncnc2[nH]cnc12</smiles>

Scheme 3. Alkylation of adenine to get the final fluorescent chemosensor.

in Scheme 3. Various combinations of heptane, chloroform and ethanol were used to check the TLC.

\section{2. Synthesis of Naked-eye Chemosensor}

\section{2. 1. Alkylation of Carbazole (4)}

To produce a naked-eye chemosensor, $9 \mathrm{H}$-carbazole was also passed through all the steps mentioned above, except the McMurry reaction, used for the alkylation of DBP. Commercially purchased $9 \mathrm{H}$-carbazole compound (Sigma Aldrich) $167 \mathrm{mg}, 0.612 \mathrm{~mL}$ of 1,3-dibromopropane, 200 $\mathrm{mg}$ of potassium carbonate and $10 \mathrm{~mL}$ acetone were mixed on magnetic stirrer for 24 hours at room temperature to obtain the alkylated carbazole as shown in Scheme 4.<smiles>Nc1ncnc2c1ncn2CCCOc1ccc(C(=C(c2ccccc2)c2ccccc2)c2ccc(OCCCn3cnc4c(N)ncnc43)cc2)cc1</smiles>

The crude mixture was poured in distilled water to dilute produced salts. The organic phase was extracted using ethyl acetate and further dried over sodium sulphate and evaporated using rotary evaporator. The extract was forwarded to purification by column chromatography. The purified product did not need any additional purification process.

\section{2. 2. Alkylation of Adenine (5)}

Of adenine base $1 \mathrm{~mol}, 2$ moles of potassium carbonate and $15 \mathrm{~mL}$ of acetone were added to $1 \mathrm{~mol}$ of the alkylated-carbazole. The reaction mixture was stirred at room temperature on magnetic stirrer for 1 day as shown in Scheme 5.

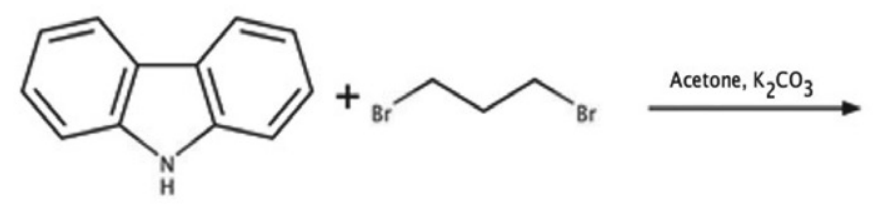




<smiles>Nc1ncnc2[nH]cnc12</smiles>

Scheme 5. Williamson ether synthesis of adenine.

\section{3. Preparation and Fixation of DNA}

DNA of Clavibacter michiganensis subsp. michiganensis $(\mathrm{Cmm})$ and Bacillus thuringiensis $(\mathrm{Bt})$ were used to test the supramolecular interactions of synthesized chemosensors. The $\mathrm{Cmm}$ isolate was growth in shaking liquid nutrient broth medium and incubated at $27^{\circ} \mathrm{C}$ with 120 $\mathrm{rpm}$ for $72 \mathrm{~h} .{ }^{22}$ Stock Bt culture was also inoculated into same liquid medium and grown as $\mathrm{Cmm}$ culture. After incubation, DNA was isolated from the performed cultures using the Gene JET Genomic DNA Purification Kit. All

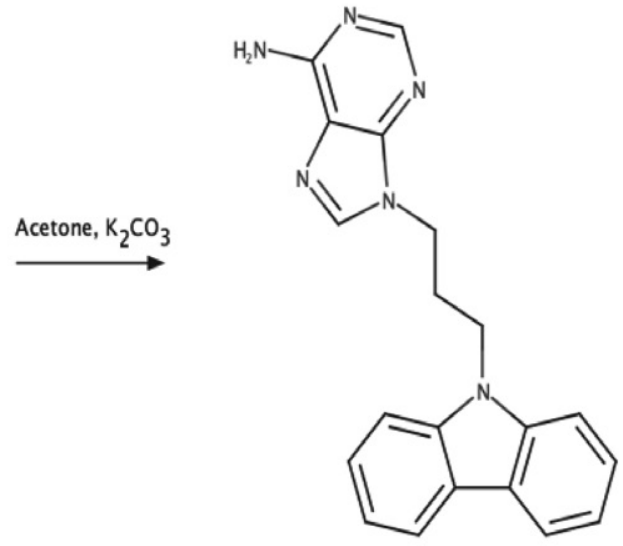

$\mathrm{Cmm}$ and Bt DNAs were denatured by diluting 1:10 in distilled water, then kept in a $95^{\circ} \mathrm{C}$ water bath for 30 minutes and chilled in ice for 15 minutes. Denatured $\mathrm{Cmm}$ and $\mathrm{Bt}$ ssDNAs $(\sim 20 \mathrm{ng} / \mu \mathrm{L})$ were separately fixed by dripping them onto nitrocellulose membranes.

\section{4. Hybridization of ssDNAs with Biosensors}

The fixed Cmm and Bt ssDNAs were dried, $10 \mu \mathrm{L}$ of chemosensors ( $\mathbf{3}$ and $\mathbf{5}$ ) were dripped separately on each

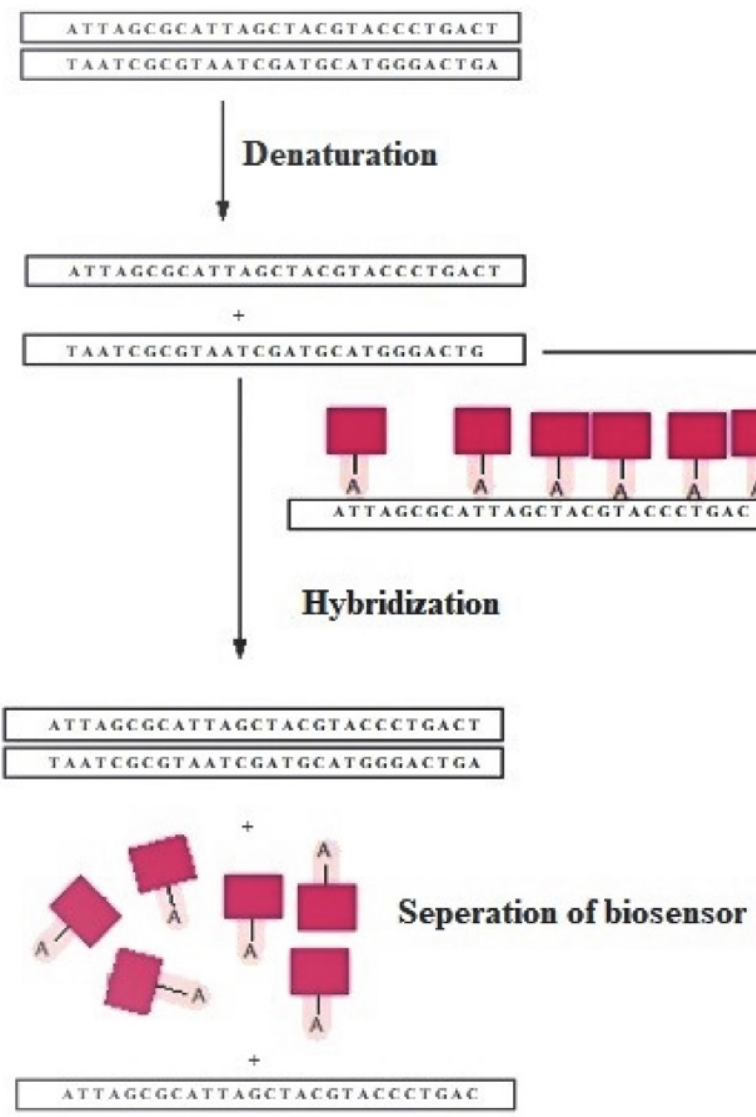

Figure 1. Separation of the biosensor from the hybrid complex with the matching of complementary ssDNAs. 
membrane. After the membranes were dried, some membranes were washed with distilled water to eliminate non-specific binding. Then, during the drying process, other $\mathrm{Cmm}$ and Bt ssDNAs $(\sim 20 \mathrm{ng} / \mu \mathrm{L})$ were dripped onto the membrane to fix DNAs of the same species. Once complementary ssDNAs had been fixed, the connection of the biosensor was established with the DNA on the fixed surface and weak adenines were washed off (Figure 1). As negative control, ssDNAs of different species were compiled together to see whether the biosensor was separated from the reaction surface. At all stages, analysis was performed by FTIR-ATR (Attenuated total reflectance) transmittance spectra.

\section{5. FTIR Analysis and Data Processing}

$\mathrm{ACD} /$ Spectrus Processor program was used to process the raw FTIR data. Correction procedures involving auto baseline correction, smoothing and auto threshold resolution procedures were applied to all data, respectively. Transmittance peak values were recorded from all data. The noise factor was set to 3 and the minimum peak intensity was set to $10 \%$. Thus, very weak bands were eliminated. IRPal 2.0 and IR Wizard 2019 beta programs were used to observe functional groups and bonds in the samples.

\section{Results}

The peaks of the methylene $\left(-\mathrm{CH}_{2}-\right)$ groups in the structure of the synthesized BSP-3 chemosensor were determined by HNMR analysis (Figure 2a). As a result of HNMR, three methylene $\left(-\mathrm{CH}_{2}^{-}\right)$groups should be observed in aromatic and aliphatic regions. Hydroxybenzophenone and benzophenone peaks were observed in the aromatic region of the HNMR spectrum at 7.02, 6.97 and $6.65 \mathrm{ppm}$. In addition, peaks were at 4.01, 3.60 and 2.27 ppm in the aliphatic methylene $\left(-\mathrm{CH}_{2}-\right)$ region. The data showed that the chemosensor was synthesized purely.

BSP-3 chemosensor known to be fluorescent emitted high fluorescence as expected when viewed under UV. Chloroform, acetone and dimethylformamide were used as mobile phase in TLC, but the chemosensor did not work with a solvent except for acetone (Figure $2 b$ ).

FTIR measurement was recorded from the empty nitrocellulose membrane as a blank (Figure 3a). Figure $3 \mathrm{~b}$ shows the FTIR analysis result recorded after Cmm ssDNA addition onto the nitrocellulose membrane. The band at $3331 \mathrm{~cm}^{-1}$ are hydrogen bands that displays stretching movements such as $\mathrm{O}-\mathrm{H}$ and $\mathrm{N}-\mathrm{H}$ in the DNA structure. The band in $1105 \mathrm{~cm}^{-1}$ shows carbon bond stretching movements such as $\mathrm{C}-\mathrm{N}, \mathrm{C}-\mathrm{C}$ and $\mathrm{C}-\mathrm{O}$, and band $\mathrm{C}-\mathrm{O}$ and $\mathrm{P}-\mathrm{O}$ stretches observed in $1029 \mathrm{~cm}^{-1}$. Phosphate group bonds are important for the proving of DNA hybridized onto the membrane.

The graphic formed after adding BSP-3 chemosensor to the membrane is shown with line in Figure 3a. Particularly, the new band at $1509 \mathrm{~cm}^{-1}$ is important to represent the $\mathrm{C}=\mathrm{C}$ double bond contained in BSP-3, on account of there is no aliphatic $\mathrm{C}=\mathrm{C}$ bond in the DNA structure. This band proved the hybridization of chemosensor onto the membrane.

In another experiment, once $\mathrm{Cmm}$ ssDNA has introduced onto the membrane, the $\mathrm{OH}$ and $\mathrm{NH}$ bands stretch at $3330 \mathrm{~cm}^{-1}, \mathrm{P}=\mathrm{O}$ bonds stretch at $1314 \mathrm{~cm}^{-1}$ and 1157 $\mathrm{cm}^{-1}$, CO, CN and CC stretches in $1106 \mathrm{~cm}^{-1}$, PO stretches in $1053 \mathrm{~cm}^{-1}$, as in the previous results (yellow line spectrum) (Figure 4a). In FTIR results obtained after BSP-3 treatment, $\mathrm{C}=\mathrm{C}$ double bond at $1622 \mathrm{~cm}^{-1}$ was detected as a sharp band (black line spectrum) (Figure $4 \mathrm{~b}$ ).

When a different Cmm ssDNA was dripped on the membrane, the $\mathrm{C}=\mathrm{C}$ sharp band disappeared as expected (blue line spectrum) (Figure 5). As we stated in our hypothesis, the chemosensor was separated from the DNA hybrid with matching the complementary DNA. With the

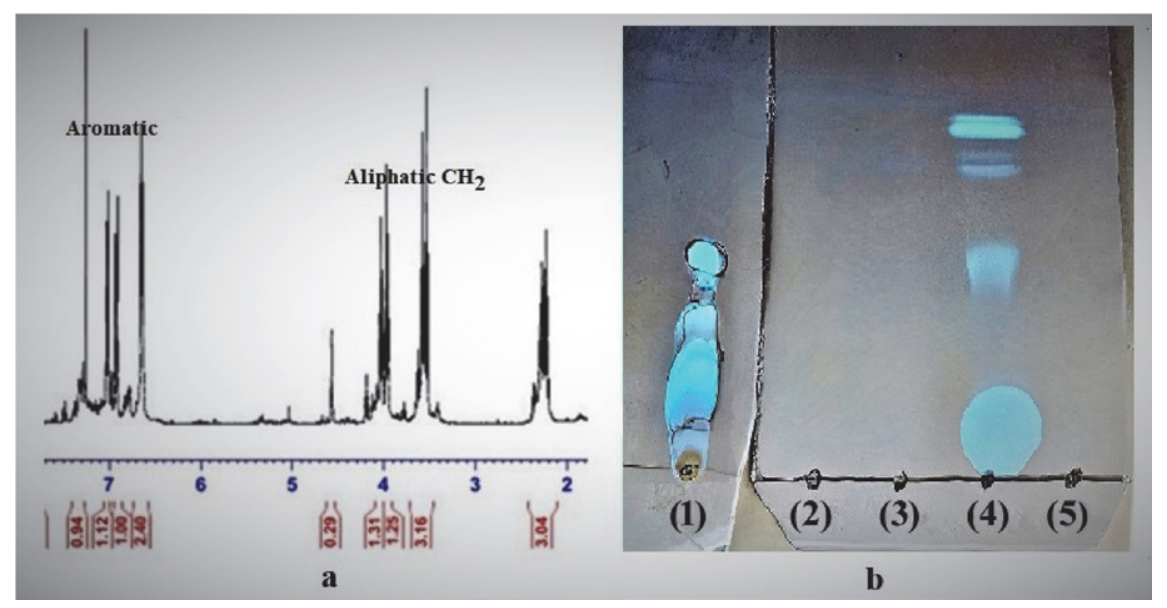

Figure 2.a. HNMR analysis of chemosensor 3; b. (1) The appearance of fluorescence BSP-3 (2) DMF, (3) Chloroform, (4) Acetone and (5) $\mathrm{H}_{2} \mathrm{O}$ under UV light on TLC. 


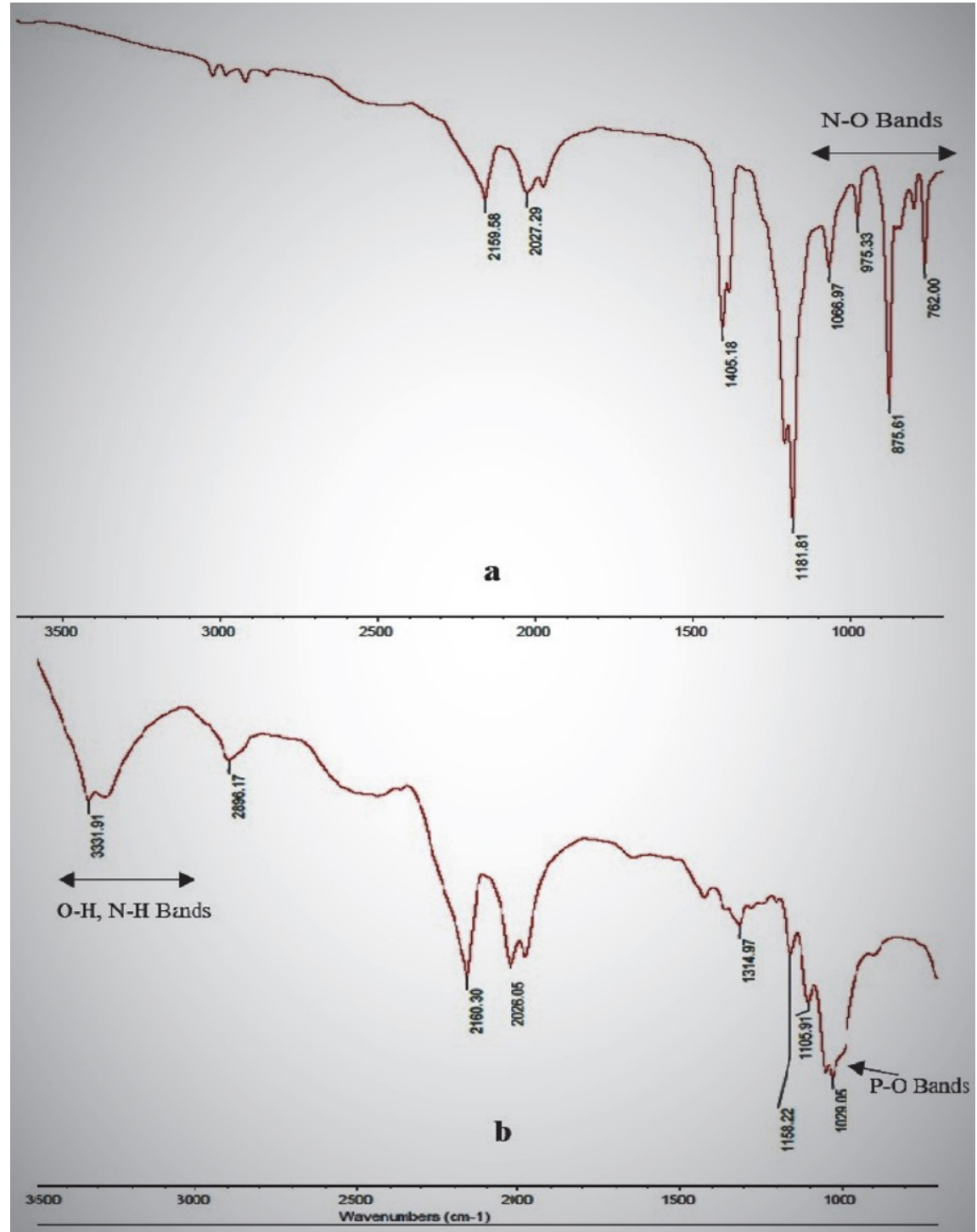

Figure 3. a. Nitrocellulose membrane (Blank) FTIR Transmittance Image, b. Membrane + Cmm ssDNA FTIR Transmittance Image.

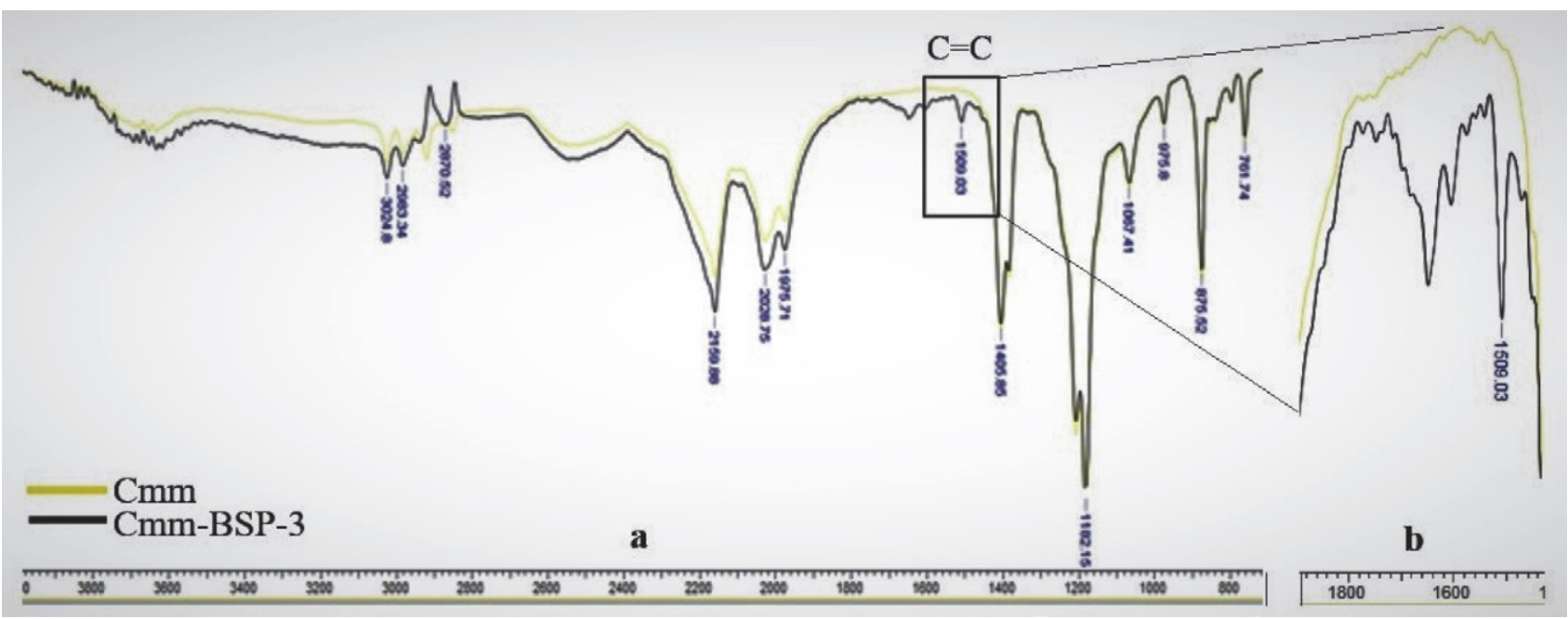

Figure 4 a. FTIR Image after BSP-3 addition $\mathbf{b}$. Zoomed FTIR image of $\mathrm{C}=\mathrm{C}$ band showing BSP-3. 


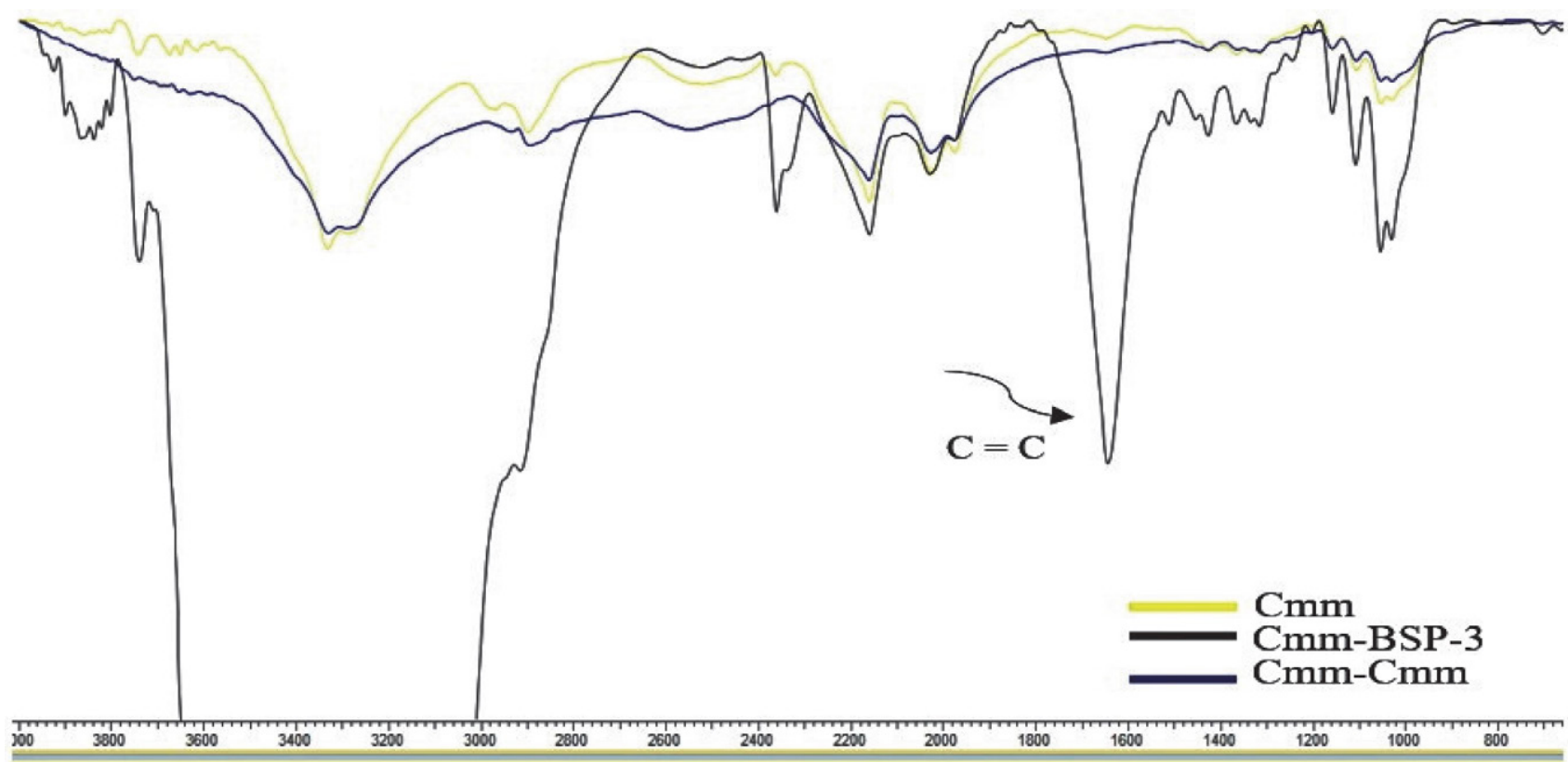

Figure 5. Band recorded by BSP-3 disappears with Cmm-Cmm hybrid.

separation of the chemosensor from the surface, it is concluded that the DNA belongs to the same species.

Different bacterial DNAs were used as negative control. As a result, to eliminate non-specific binding after BSP-3 treatment, the membrane washed off with distilled water. After rinsing, Bt ssDNA was dripped onto the membrane. In further step, it is expected that the BSP-3 chemosensor will not release from the hybrid and the $\mathrm{C}=\mathrm{C}$ bond will continue to appear as a result of FTIR cause of non-complementary ssDNAs. In fact, our hypothesis was confirmed in FTIR analysis. In Figure 6, the presence of the band recorded by BSP-3 at $1648 \mathrm{~cm}^{-1}$ after rinsing and Bt ssDNA treatment is shown as vertical and horizontally zoomed.

Bt-Bt hybrid was used with carbazole in the experiment. Peak was observed at $1652 \mathrm{~cm}^{-1}$ after the carbazole treatment. These observed peaks are much sharper after rinsing. When the second Bt ssDNA was added, these peaks became very weak. This means that the signal observed by the chemosensor becomes weaker (Figure 7).

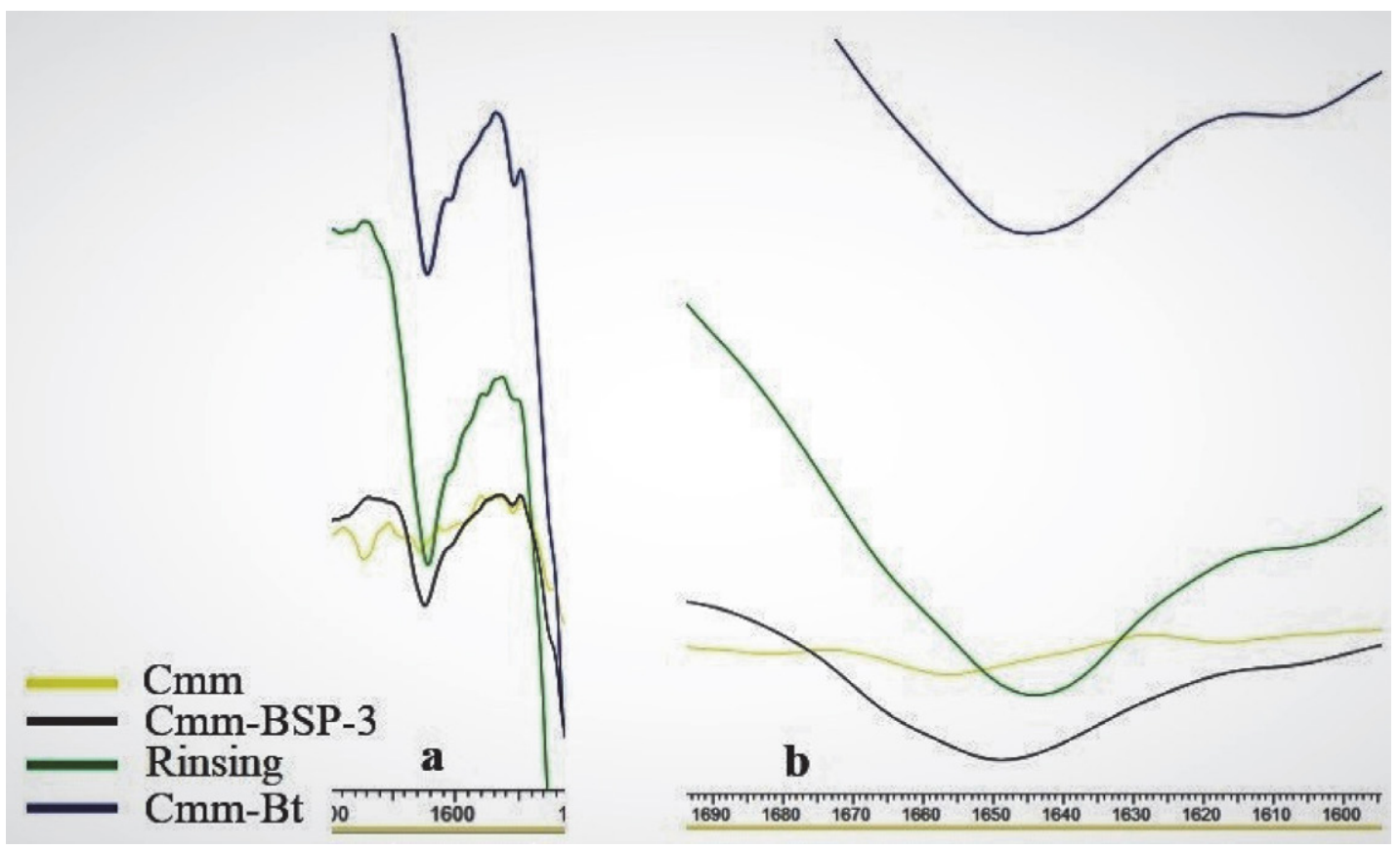

Figure 6. a. Vertical zoomed FTIR bands, b. horizontal zoomed FTIR bands. BSP-3 chemosensor emits the signal due to non-complementary ssDNAs. 


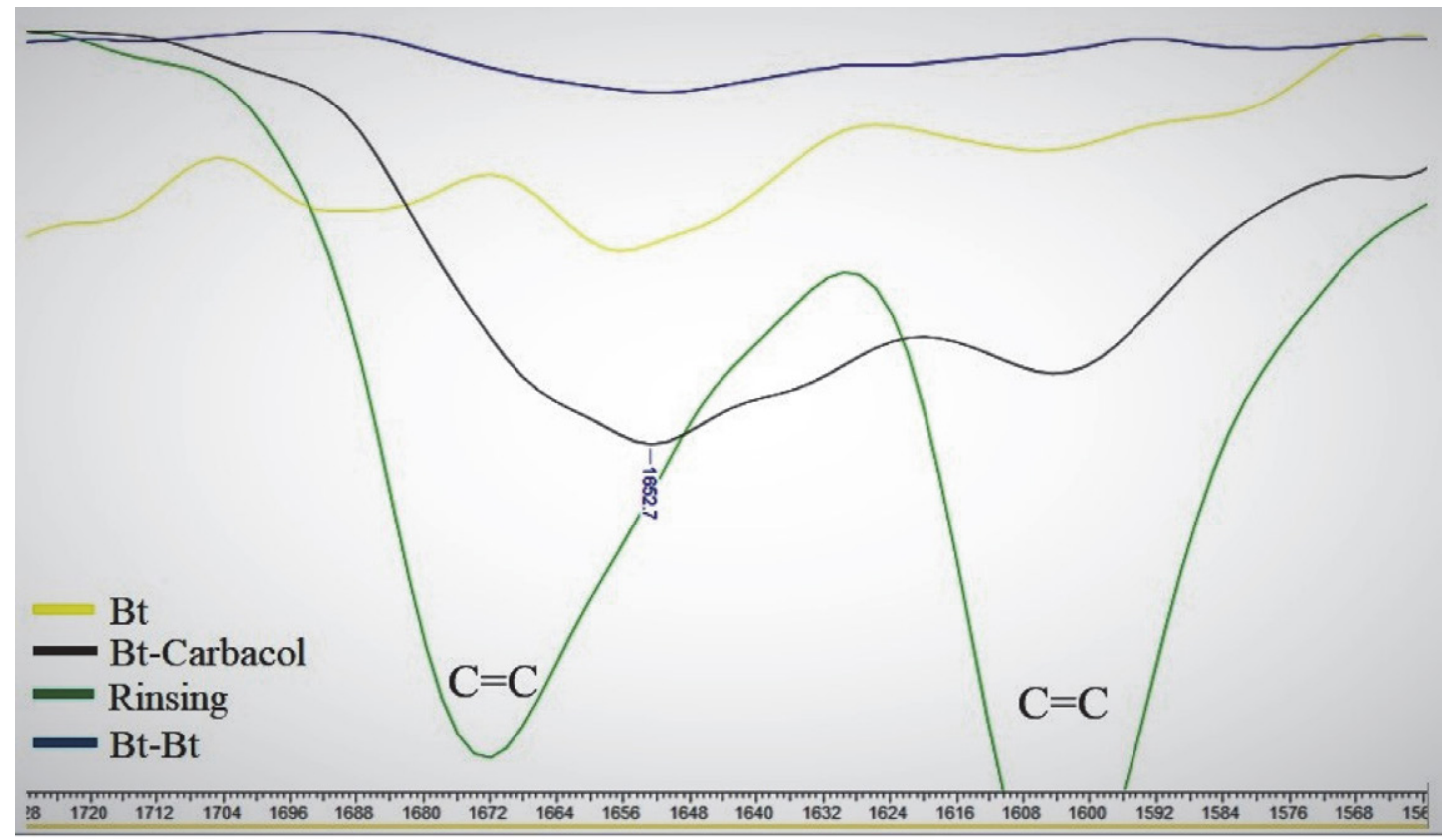

Figure 7. The peaks of carbazole disappear after the Bt-Bt matching at 1600 and $1672 \mathrm{~cm}^{-1}$.

\section{Discussion}

In our study, we have developed a diagnostic method that relies on DNA-based ssDNA chain and chemosensor hybridization. Our method involves a different and novel version of the chemosensor used by Arulraj et al. 2015, which changes its fluorescence due to the presence of $\mathrm{Ag}^{+}$ in the environment. ${ }^{23}$ Our synthesized chemosensor enables us to diagnose based on DNA replacing $\mathrm{Ag}^{+}$and depending on the changes with IR spectrum. The synthesized chemosensors have fluorescent properties and they can be detected under UV lamp after synthesis cause of its emitting fluorescence. We have examined in detail whether the product obtained at every step of the synthesis is pure as a targeted molecule. Benzophenone and hydroxybenzophenone peaks in the chemosensor were detected by NMR analysis. In addition, the aliphatic methylene $\left(-\mathrm{CH}_{2}-\right)$ peaks showed that synthesis was completed.

The rapid diagnosis with high accuracy using FTIR analysis can be suggested by BSP-3. Due to bands of BSP-3 with densities varying between $6-10 \%$, the desired difference could not be achieved in some trials. By keeping the noise factor high, we minimized the bands which may cause the deceptive measurements.

Another compound used as a chemosensor was carbazole. It has been stated that carbazole can bind to human telomeric G-quadruple DNA and stabilizes and the previous studies indicated it as an anti-carcinogenic agent. ${ }^{24,25}$ As a pioneer study, we showed the carbazole as a chemosensor that could also bind to microbial DNA. In the diagnosis with carbazole, the actions of aromatic $\mathrm{C}=\mathrm{C}$ bonds were used by BSP-3. Although the presence of aromatic C $=\mathrm{C}$ bonds in DNA bases causes a problem, the carbazole separation was followed from the hybrid-formation depending on the band density. In the experiment with carbazole, rinsing with water increased the severity of the peak recorded by the carbazole.

Diagnostic methods using chemosensors seem a good alternative to conventional methods such as PCR. ${ }^{26}$ Most DNA chemosensor techniques are based on hybridization techniques in which DNA is detected by electroluminescence, fluorescence or calorimetric methods. ${ }^{26}$ The diagnostic method based on chemosensor as a prototype kit designed in our study mimics other methods in terms of fixing the DNA to a surface and measurements relied on hybridization. The most prominent aspect that distinguish our diagnostic kit of other suggested methods is the use of whole DNA as a template and the measurement of its hybridization. In other tested methods, while the measurement is performed in the form of detecting the DNA bound to the chemosensor, in our study it works with the detection of the chemosensor separated from the environment which resulted the binding of the complementary ssDNA. ${ }^{26}$ Since the method detects indirectly, its sensitivity and accuracy ratio could be relatively lower than other methods relied on direct hybridization. In addition, the method has advantages, it does not require expensive equipment and can be applied practically compared to other detection methods.

The accurate and reliable results of the developed diagnostic kit are promising for future studies. It is possible that this kit, which can diagnose DNA quickly and precisely with a new technique, will become even more comprehensive by further studies. For example, the use of a triple hydrogen bonding guanine or cytosine base instead of the 
adenine base is another option. There are many variables such as concentrations of DNA, additional chemosensors, hybridization temperatures and drying times of membranes. These factors can be considered as the primary actions for the diagnosis to work with an accuracy of almost $100 \%$ by setting them according to optimum standards. Moreover, it seems possible to convert the bacterial DNA diagnostic kit, which we have presented as a prototype, into a commercial product.

\section{Conclusion}

A hydroxybenzophenone-based fluorescence chemosensor and a carbazole-based naked-eye chemosensor were both prepared separately. The idea was to utilize the supramolecular interactions of adenine with thymine in the identification of DNA-based pathogens. Adenine was chemically binded to the both chemosensors and settled over the ssDNA, thereby the adenine of the chemosensor would bind to the thymine of the ssDNA. As ssDNA binds with the same exact ssDNA more strongly, it was supposed that the presence of the same ssDNA would remove the adenine of chemosensor from the immobilized ssDNA. Supramolecular interactions of the adenine-chemosensor with the ssDNA were analyzed using FTIR spectra that clearly showed the tested ssDNA removes the adenine-chemosensor from the immobilized ssDNA when both ssDNA were the same. However, sophisticated techniques are necessary to obtain optimum conditions affecting different parameters such as $\mathrm{pH}$, solvent, temperature and buffer required for kit manufacturing in commercialization process. Our method will provide rapid and most accurate fingerprint to identify any kind of pathogen with further studies.

\section{Acknowledgement}

The authors wish to thank Scientific Research Projects Department of Muğla Sttkı Koçman University for financial support with projects Nr.17/090 and Nr.19/082/03/1/2 and to Merve Çolak, Suna Savran for technical assistance concerning chemosensor synthesis process.

\section{References}

1. Y. Du, S. Dong, Anal. Chem. 2017, 89, 189-215.

DOI:10.1021/acs.analchem.6b04190

2. F. Teles, L. P. Fonseca, Talanta. 2008, 77, 606-623.

DOI:10.1016/j.talanta.2008.07.024

3. T. G. Drummond, M. G. Hill, J. K. Barton, Nat. Biotechnol. 2003, 21, 1192-1199. DOI:10.1038/nbt873

4. A. Sassolas, B. D. Leca-Bouvier, L. J. Blum, Chem. Rev. 2008, 108, 109-139. DOI:10.1021/cr0684467

5. B. Şener, Rapid Diagnostic Kit Design for Bacterial Cancer
Diagnosis. Master Thesis. Thesis Nr. 650831, Muğla Sıtkı Koçman University, Muğla, 2020, 96 p. (In Turkish).

6. K. J., Odenthal, J. J. Gooding, Analyst. 2007, 132, 603-610. DOI:10.1039/b701816a

7. M. Minunni, S. Tombelli, E. Mariotti, M. Mascini, M. Mascini, Fresenius J. Anal. Chem. 2001, 369, 589-593. DOI:10.1007/s002160100761

8. S. Hahn, S. Mergenthaler, B. Zimmermann, W. Holzgreve, Bioelectrochemistry, 2005, 67, 151-154. DOI:10.1016/j.bioelechem.2004.07.006

9. H. Nakamura, I. Karube, Anal. Bioanal. Chem. 2003, 377, 446-468. DOI:10.1007/s00216-003-1947-5

10. A. Muthukumar, N. L. Zitterkopf, D. Payne, Lab. Med. 2008, 39, 430-436 DOI:10.1309/M6MBU1KGP0FF1C00

11. X. Chu, X. Dou, R. Liang, M. Li, W. Kong, X. Yang, J. Luo, M. Yang, M. Zhao, Nanoscale, 2016, 8, 4127-4133. DOI:10.1039/C5NR08284F

12. S. Dai, S. Wu, N. Duan, Z. Wang, Talanta. 2016, 158, 246-253. DOI:10.1016/j.talanta.2016.05.063

13. Y. Teng, X. Jia, S. Zhang, J. Zhu, E. Wang, Chem. Commun. 2016, 52, 1721-1724. DOI:10.1039/C5CC09138A

14. Z. Izadi, M. Sheikh-Zeinoddin, A. A. Ensafi, S. Soleimanian-Zad, Biosens. Bioelectron. 2016, 80, 582-589.

DOI:10.1016/j.bios.2016.02.032

15. L. Potocki, J. Depciuch, E. Kuna, M. Worek, A. Lewinska, M. Wnuk, Int. J. Mol. Sci. 2019, 20, 988.

DOI:10.3390/ijms20040988

16. A. M. Hamad, H. M. Fahmy, W. M. Elshemey, Radiat. Phys. Chem. 2020, 166, 108522,

DOI:10.1016/j.radphyschem.2019.108522

17. J. D. Fredericks, P. Bennett, A. Williams, K. D. Rogers, Genetics. 2012, 6, 375-380. DOI:10.1016/j.fsigen.2011.07.014

18. R. E. Kirk, D. F. Othmer, Encyclopedia of Chemical Technology, 5th edition, Wiley, New York, 2004, 864 p.

19. N. Jaggi, D. Vij, in: D. Vij (Ed.), Handbook of Applied Solid State Spectroscopy, Springer, Boston, 2006, pp. 411-450.

20. J. Coates, in: R. A. Meyers (Ed.), Encyclopedia of Analytical Chemistry, John Wiley \& Sons Ltd, Chichester, 2000, pp. 10815-10837.

21. A. B. D. Nandiyanto, R. Oktiani, R. Ragadhita, Indones. J. Sci. Technol. 2019, 4, 97-118. DOI:10.17509/ijost.v4i1.15806

22. Ö. Baysal, F. Mercati, H. İkten, R. Ç. Yıldız, F. Carimi, Y. Aysan, J. A. Teixeira da Silva, Physiol. Mol. Plant Pathol. 2011, 75, 113-119. DOI:10.1016/j.pmpp.2010.10.002

23. A. D. Arulraj, R. Devasenathipathy, S-M. Chen, V. S. Vasantha, S-F. Wang, Sens. Biosensing Res. 2015, 6, 19-24.

DOI:10.1016/j.sbsr.2015.10.004

24. A. Głuszyńska, B. Juskowiak, B. Rubiś, Molecules (Basel, Switzerland), 2018, 23, 3154.

DOI:10.3390/molecules23123154

25. C. C. Chang, J. Y. Wu, C. W. Chien, W. S. Wu, H. Liu, C. C. Kang, L. J. Yu, T. C. Chang, Anal. Chem. 2003, 75, 6177-6183. DOI:10.1021/ac034789i

26. M. Khater, A. de la Escosura-Muñiz, A. Merkoçi, Biosens. Bioelectron. 2017, 93, 72-86.

DOI:10.1016/j.bios.2016.09.091 


\section{Povzetek}

Detekcija in identifikacija patogenih bakterij zahteva razvoj hitrih in zanesljivih metod temelečih na značilnem DNA odtisu. V tem delu poročamo o razvoju inteligentnega kemosenzorja s terminalnim adeninom, ki se poveže s timinom enovijačne DNA (ssDNA) preko supramolekularnih interakcij ter se sprosti z enovijačne DNA v prisotnosti ujemajoče DNA. Pripravili smo kemosenzor osnovi karbazola, katerega obarvanost je mogoče zaznati s prostim očesom. Kot modelni genski material smo uporabili enovijačno DNA Clavibacter michiganensis podvrste michiganensis, ki smo jo imobilizirali na nitrocelulozno membrano. Sintetiziran adeninski kemosenzor smo prečrpali skozi membrano z imobilizirano enovijačno DNA pri čemer se je nanjo vezal in tvoril ssDNA nitrocelulozni-ssDNA-adeninski-kemosenzor. FTIR analiza imobilizirane enovijačne DNA je pokazala, da prisotnost ujemajoče enovijačne DNA povzroča sproščanje adeninske kemosenzorja in tvorbo dvovijačne DNA. Selektivnost kemosenzorja je bila potrjena $\mathrm{z}$ uporabe kontrolne DNA Bacillus subtilis. Podatki kažejo, da je metoda točna in zanesljiva ter predstavlja prototip diagnostičnega kita za hitro in natančno določanje DNA.

Except when otherwise noted, articles in this journal are published under the terms and conditions of the Creative Commons Attribution 4.0 International License 